\title{
Comparative study of technique to obtain stem cells from bone marrow collection between the iliac crest and the femoral epiphysis in rabbits ${ }^{1}$
}

\author{
Estudo comparativo da técnica para a obtenção de células tronco pela coleta de medula óssea \\ entre a crista ilíaca e epífise do fêmur em coelhos
} \author{
Ferreira $^{\text {VI }}$, Marcelo Paulo Vaccari Mazzetti ${ }^{\mathrm{VII}}$

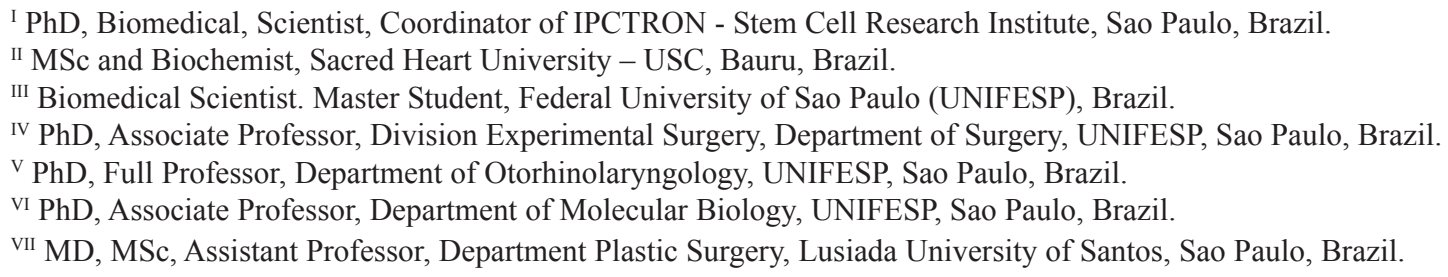

Lilian Piñero Eça', Renata Belmonte Ramalho", Isis Sousa Oliveira ${ }^{\mathrm{III}}$, Paulo Oliveira Gomes ${ }^{\mathrm{IV}}$, Paulo Pontes ${ }^{\mathrm{V}}$, Alice Teixeira

\begin{abstract}
Purpose: To assess the technique for the collection of rabbit bone marrow stem cells from different regions to be used as an experimental model in regenerative medicine. Methods: Thirty rabbits were allocated into 2 groups: GROUP A, n=8, animals that underwent bone marrow blood (BMB) harvesting from the iliac crest; and GROUP B: including 22 rabbits that underwent BMB harvesting from the femur epiphysis. After harvesting, mononuclear cells were isolated by density gradient centrifugation (Ficoll - Histopaque). The number of mononuclear cells per ml was counted in a Neubauer chamber and cell viability was checked through Tripan Blue method. Results: Harvesting from the iliac crest yielded an average of $1 \mathrm{ml}$ of BMB and 3,6.10 cells/ml over 1 hour of surgery, whereas an average of $3 \mathrm{ml}$ of $\mathrm{BMB}$ and $11,79.10^{6}$ cells./ml were obtained in $30 \mathrm{~min}$ from the femur epiphysis with a reduced animal death rate. Conclusion: The analysis for the obtention of a larger number of mononuclear cells $/ \mathrm{ml}$ from rabbit bone marrow blood was more satisfactory in the femur epiphysis than in the iliac crest.
\end{abstract}

Key words: Bone Marrow. Adult Stem Cells. Rabbits.

\section{RESUMO}

Objetivo: Avaliar a técnica mais promissora para a coleta de células tronco adultas de medula óssea de coelhos para a utilização do mesmo como modelo experimental na medicina regenerativa. Métodos: Foram utilizados 30 coelhos divididos em 2 grupos: GRUPO A, $\mathrm{n}=8$, onde realizamos a coleta de sangue de medula óssea (MO) da crista ilíaca e grupo $\mathrm{B}, \mathrm{n}=22$, onde realizamos a coleta de sangue da medula óssea da epífise do fêmur. Após as coletas, realizamos a separação das células mononucleadas através do gradiente de densidade (Ficoll-Hystopaque). Através da câmara de Neubauer realizamos a contagem das células mononucleadas por ml. Testamos a viabilidade celular através do método Tripan Blue. Resultados: Na coleta de sangue de MO na crista ilíaca obtivemos a média de $1 \mathrm{ml}$ durante 1 hora de procedimento cirúrgico, obtendo a quantidade de 3,6 .10 células $/ \mathrm{ml}$, enquanto que a punção na epífise do fêmur obtivemos a média de $3 \mathrm{ml}$ durante 30 minutos de procedimento cirúrgico obtendo a quantidade de $11,79.10^{6}$ cél./ml diminuindo o óbito dos animais. Conclusão: A análise para a obtenção de maior número de células mononucleadas $/ \mathrm{ml}$ de sangue de medula óssea de coelho foi mais satisfatória na região da epífise do fêmur em comparação com a crista ilíaca.

Descritores: Medula Óssea. Células-Tronco Adultas. Coelhos.

${ }^{1}$ Research performed in Stem Cell Research Institute - IPCTRON and Otorhinolaryngology Advance Science Institute - ICAO under partnership of Bauru Sacred Heart University - USC, Brazil.

\section{Introduction}

The primary role of adult stem cells (ASC) in a living organism is to maintain and repair the tissue in which they are found. The term somatic stem cell can be used to designate adult stem cells. Unlike embryonic stem cells, which are defined by their origin, the inner cell mass of the blastocyst, the origin of adult stem cells is unknown ${ }^{1}$. Jiang Y et al. ${ }^{2}$ were the first to observe the presence of adult stem cells in several tissues, leading to the hypothesis that adult stem cells could be used for transplants, as bone marrow blood is used to treat leukemia.

The history of research on ASC began about 40 years ago. In the 1960s, researchers discovered that the bone marrow contains at least two kinds of stem cells. One population, called 
hematopoietic stem cells, forms all the types of blood cells in the body. A second population, called bone marrow stromal or mesenchymal cells, was discovered a few years later. Stromal cells are a mixed cell population that generates bone, cartilage, fat, and fibrous connective tissue, among others. One important point to understand about adult stem cells is that there are a very small number of stem cells in each tissue. Stem cells are thought to reside in a specific area of each tissue where they may remain quiescent (non-dividing) for many years until they are activated by disease or tissue injury. The adult tissues reported to contain stem cells include brain, bone marrow, peripheral blood, blood vessels, skeletal muscle, skin and liver ${ }^{3}$.

The tests used for identifying adult stem cells include:

(1) labeling the cells in a living tissue with molecular markers and then determining the specialized cell types they generate;

(2) removing the cells from a living animal, labeling them in cell culture, and transplanting them back into another animal to determine whether the cells repopulate their tissue of origin; and

(3) isolating the cells, growing them in cell culture, and manipulating them, often by adding growth factors or introducing new genes, to determine what differentiated cells types they can become

Adult stem cells occur in many tissues and enter normal differentiation pathways to form the specialized cell types of the tissue in which they reside. ASC may also exhibit the ability to form specialized cell types of other tissues, which is known as transdifferentiation or plasticity ${ }^{4}$.

In a living animal, adult stem cells can divide for a long period and can give rise to mature cell types that have characteristic shapes and specialized structures and functions of a particular tissue. Hematopoietic stem cells (HSC) give rise to all the types of blood cells. Mesenchymal stem cells (MSC) give rise to bone cells (osteocytes), cartilage cells (chondrocytes), fat cells (adipocytes), and other kinds of connective tissue cells such as those in tendons.
Neural stem cells (NST) give rise to three major cell types: neurons, astrocytes and oligodendrocytes. Epithelial stem cells (ESC) give rise to absorptive cells, goblet cells, Paneth cells, and enteroendocrine cells. Skin stem cells (SSC) occur in the basal layer of the epidermis and at the base of hair follicles. Epidermal stem cells (ESC) give rise to keratinocytes, which migrate to the surface of the skin and form a protective layer. Follicular stem cells (FSC)can give rise to both the hair follicle and to the epidermis ${ }^{5}$.

ASC are pluripotent. This ability to differentiate into multiple cell types is called plasticity or transdifferentiation ${ }^{6}$.

Current research is aimed at determining the mechanisms that underlie adult stem cell plasticity. If such mechanisms can be identified and controlled, existing stem cells from a healthy tissue might be induced to repair a diseased tissue ${ }^{7}$.

\section{Purpose}

To assess the technique for the collection of rabbit bone marrow stem cells from different regions to be used as an experimental model in regenerative medicine

\section{Methods}

This study was approved by Committee on Ethics in research of the Bauru Sacred Heart University-USC,

Male New Zealand rabbits $(\mathrm{n}=30)$ aged 5-6 months and weighing $3.0-3.5 \mathrm{~kg}$ were used. All animals (provided by $\mathrm{Criex}^{\mathrm{TM}}$ ) were housed in individual cages and allowed access to water and rabbit chow ad libitum. Each rabbit was assigned an individual ID and was kept at the ICAO Bioterium-SP.

The animals were distribuited in: Group A - twenty two rabbits submitted to the harvested by puncturing the bone marrow blood femoral epiphysis and Group B - eight rabbits submitted to the harvested by puncturing the bone marrow blood iliac crest (Figure 1).

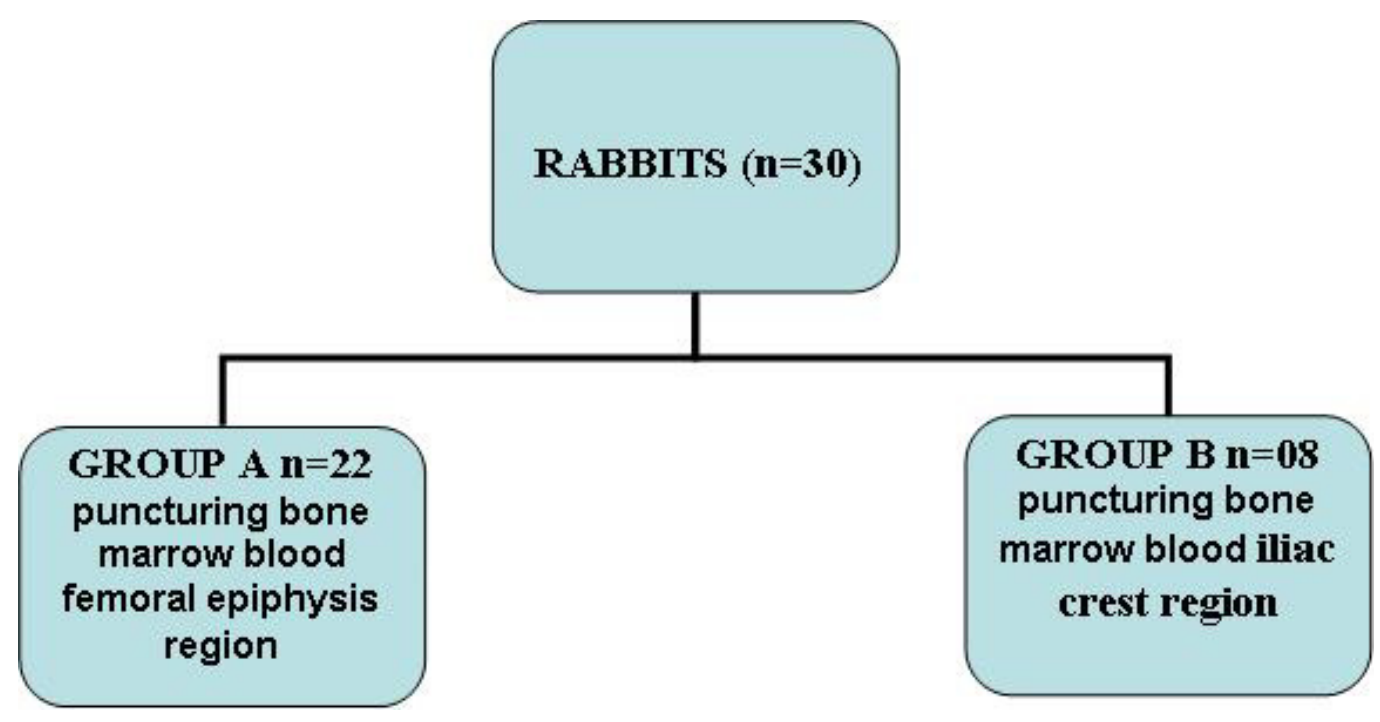

FIGURE 1 - Animals distribution in different study group 
A $2 \mathrm{~cm}$ skin incision was made with a 15 blade in the iliac crest and the femoral epiphysis region localized by comparison with the dissected skeleton (Figure 2A) of another animal. The muscle was sectioned up to the femoral bone. Bone marrow blood was harvested $(2-3 \mathrm{ml})$ by puncturing the iliac crest and the femoral epiphysis with a bone marrow puncture needle (Komiyashiki needle, gauge 12) that was inserted and carefully rotated until the medullary cavity was reached (Figure 2B). The mandrill was removed and bone marrow was aspirated with a 5 -ml syringe containing $5000 \mathrm{UI} / \mathrm{ml}$ of heparin ${ }^{8}$. (Figure 2C). Immediately after punction, blood was transferred to a vacuum tube containing 5000 $\mathrm{UI} / \mathrm{ml}$ of heparin (Figure 2D).
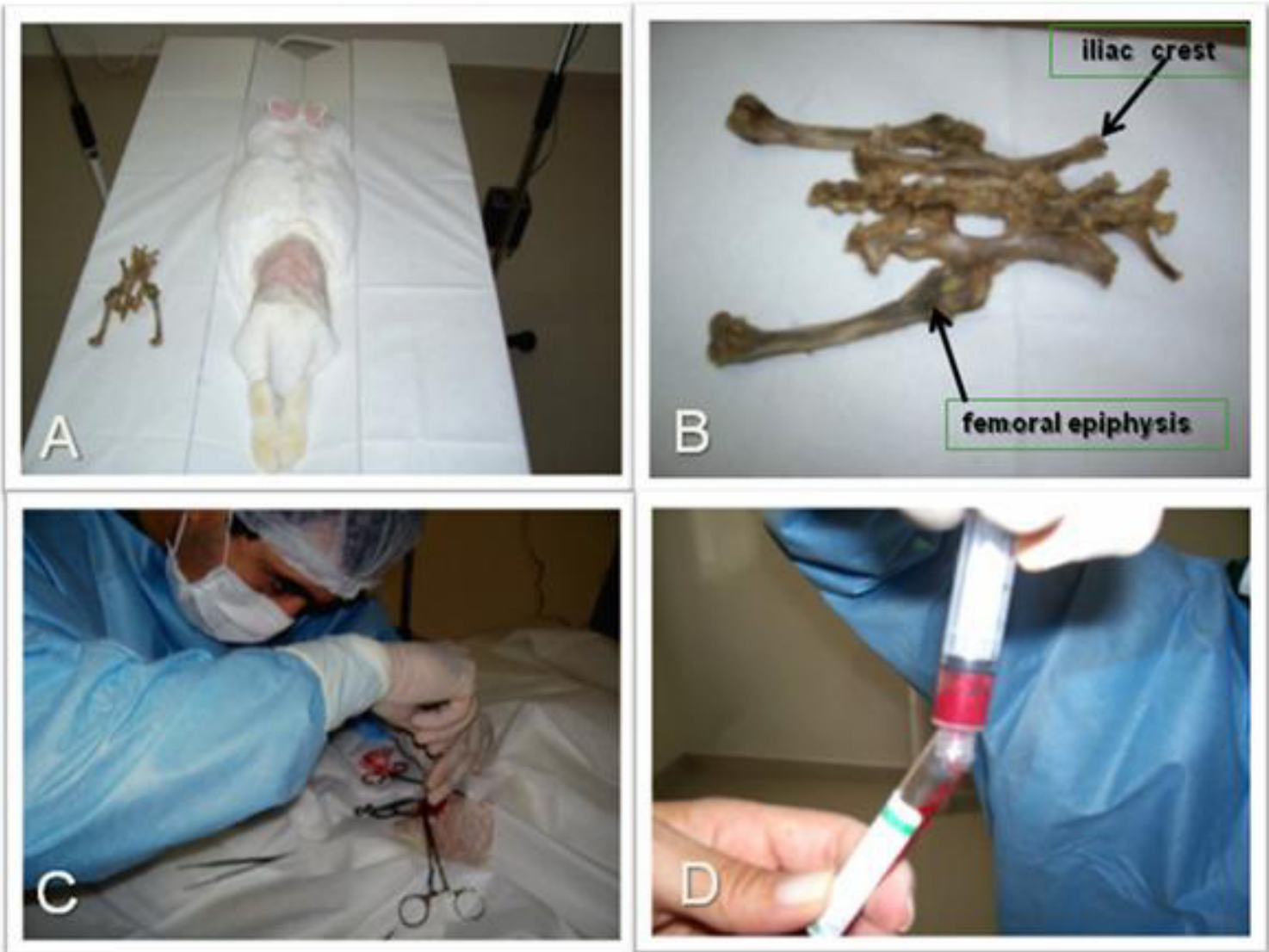

FIGURE 2 - Rabbit (A) iliac crest and the femoral epiphysis region (B) punction (C) and bone marrow blood (D)

The total volume of bone marrow blood $(2 \mathrm{ml})$ was used for mononuclear cell isolation by gradient centrifugation at 2000 rpm for 30 minutes at room temperature on Ficoll-Hystopaque (1077 density). The mononuclear cell layer was aspirated with a pipette, washed twice for Ficoll-Hystopaque removal, and resuspended in DMEM medium (Figure 3).

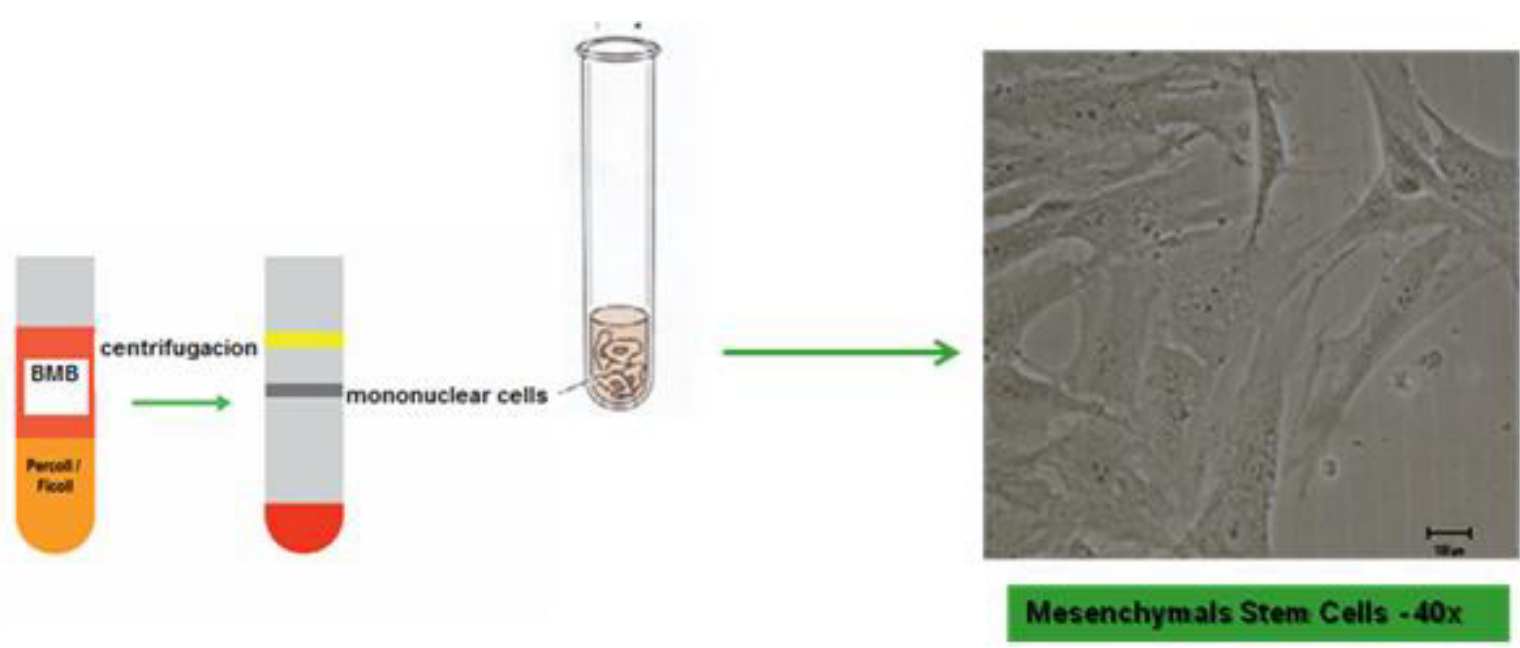

FIGURE 3 - Colorless mononuclear cell layer 
Cells were prepared with $1 \mu \mathrm{l}$ of cell suspension and placed in a Neubauer chamber. The number of cells was estimated as: A quadrant delimited the area observed under the microscope using 10x ocular and 10x objective. In order to convert the number of cells counted in this quadrant into cell $/ \mathrm{ml}$, a correction factor of $10^{4}$ was used.

After counting, cell viability was checked by the Tripan blue dye exclusion method, which traverses the membrane in a dead cell and dyes it blue. Cells were prepared by adding $1 \mu 1$ of cell suspension to $1 \mu 1$ of Tripan blue $1: 1$.

Data were expressed as mean \pm standard deviation. The $t$ test of Student for paired samples was used for comparison between groups. Statistical significance was set at $\mathrm{p} \leq 0.05$

\section{Procedures}

The antibiotic clindamicine was prophylactically administered 24 hours before surgery.

On the following day, the animals were anesthetized with an intramuscular injection of zoletil $(0.4 \mathrm{ml} / \mathrm{kg})$ and ketamine $(0.4 \mathrm{ml} / \mathrm{kg})$. For maintenance, this dose was diluted into $10 \mathrm{ml}$ of sterile saline intramuscularly injected $(1.0-2.0 \mathrm{ml})$ when necessary.

The surgical site was shaved, scrubbed with a Rioex ${ }^{\mathrm{TM}}$ solution (Chlorhexidine 2\%), and covered with a sterile adhesive film to reduce the risk of contamination.

Local hemostasis was achieved by infiltrating lidocaine $2 \%$ in the incision during surgery.

\section{Results}

Comparison between iliac crest and femur epiphysis harvesting in rabbits

When harvesting bone marrow blood from the iliac crest in rabbits $(n=8)$, it was very difficult to obtain the ideal average amount of $3 \mathrm{ml}$. Indeed, only $1 \mathrm{ml}$ of bone marrow blood was obtained by puncture. Furthermore, the procedure took up to 1 hour to be completed and caused animals to die.

Therefore, the harvesting site was changed to the femur epiphysis $(n=22)$ allowing the collection of an average of $3 \mathrm{ml}$ of bone marrow blood in 20-30 minutes with a reduced level of animal suffering (Figure 4).

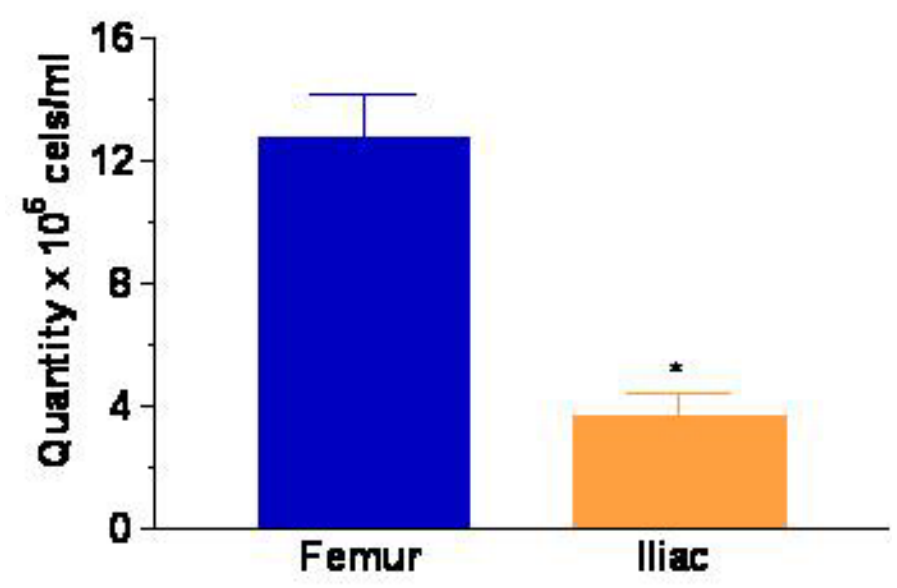

FIGURE 4 - Mononuclear cell count in different volumes of epiphysis femur and iliac crest, volume of $1,0 \mathrm{ml}(\mathrm{n}=8) 3,6.10^{6} \pm 0,50$ cell $/ \mathrm{ml}$ and volume of $3,0 \mathrm{ml}(\mathrm{n}=22) \quad 12.10^{6} \pm 1,37 \mathrm{cell} / \mathrm{ml}($ test $\mathrm{t} * \mathrm{p} \leq 0.05)$

\section{Cell viability}

Cell viability testing revealed that $98 \%$ of the cells were viable, i.e., not stained with Tripan blue. Given that Tripan blue has a high affinity to nuclear DNA, its absence demonstrated that the cells were whole and fit to be used in the experiments as shown in the Figure 5.

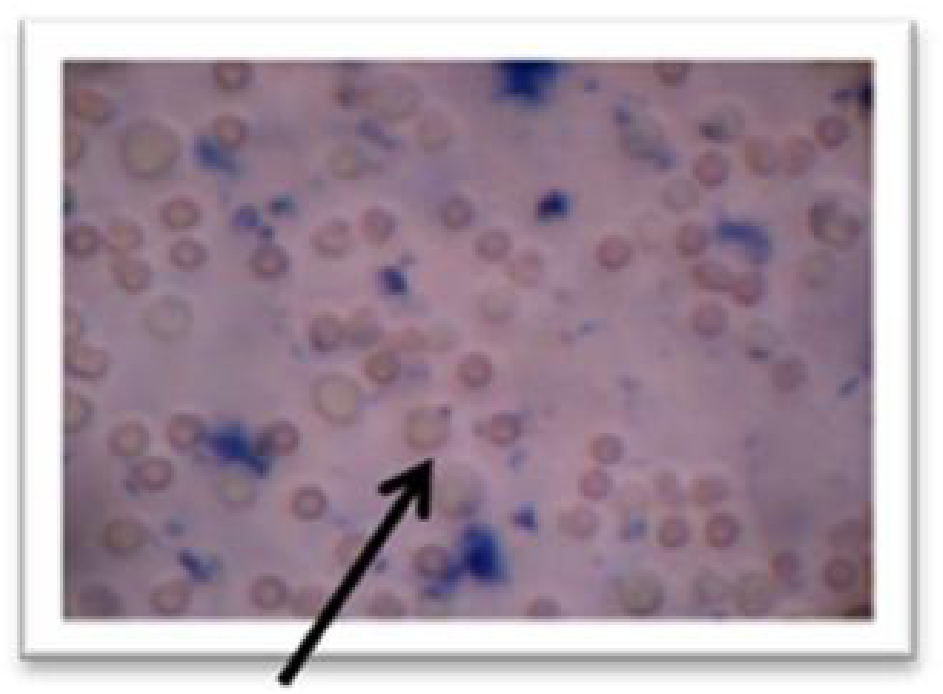

FIGURE 5 - Mononuclear cells stained with Tripan blue cell viability of $98 \%$ (incolor cells)

\section{Discussion}

Mesenchymal stem cells are a very promising source of new alternative therapies. They have two very important characteristics: self-renewal and differentiation potential. Furthermore, stem cells from different organs and tissues (heart, liver, brain, bone marrow, muscles, spleen) can be derived and propagated in vitro ${ }^{11,12,13,14}$.

To date, isolating human stem cells from healthy tissues has proven to be a difficult task. These cells have been usually isolated by aspirating blood marrow blood from the upper iliac crest, tibia, femur, or lumbar and thoracic spine.

The best site for bone marrow stem cell harvesting remains to be determined.

Most experimental studies have used iliac crest puncture to obtain blood marrow blood, which is a source of hematopoietic and mesenchymal stem cells, as well as other mononuclear cells lymphocytes and monocytes.

Bianco et al. ${ }^{15}$, demonstrated that blood marrow blood collected by density gradient separation allowed the isolation of mononuclear cells at a minimum concentration of $1 \times 10^{6}$ cells $/ \mathrm{ml}$ whereas found $12 \times 10^{6}$ cells $/ \mathrm{ml}$ at the most.

In this study, the number of mononuclear cells obtained from femoral blood marrow was higher than that reported in the literature. However, when the iliac crest was used as the donor site, as commonly described in the literature, the number of mononuclear cells was smaller (average of $3 \times 10^{6}$ cells/ ml) $(\mathrm{p} \leq 0.05)$.

Kadiyala et al. ${ }^{16}$, observed that mesenchymal stem cells represented $1 \%$ of the total number of bone marrow-derived mononuclear cells. In this study, $12 \times 10^{4}$ cells/ ml were obtained from the femur while only $3 \times 10^{4}$ cells/ $\mathrm{ml}$ were obtained from the iliac crest. 
No optimal stem cell number has been established in the literature. However, our knowledge leads us to believe that the greater the number of cells available the better tissue repair.

Thus, comparing harvesting regions to find out which one is best for bone marrow blood collection, as well as assessing the number of mononuclear cells obtained from these regions in a rabbit model can help identify the anatomical sites from which a larger number of mononuclear stem cells can be obtained, and will allow the conduction of studies to determine the most effective cell number for tissue regeneration ${ }^{17}$.

\section{Conclusion}

The analysis for the obtention of a larger number of mononuclear cells/ml from rabbit bone marrow blood was more satisfactory in the femur epiphysis than in the iliac crest.

\section{References}

1. Slack JM. Stem cells in epithelial tissues. Science. 2000;287(5457):1431-3. 2. Jiang Y, Balkrishna NJ, Reinhardt RL, Schwartz RE, Keene CD, Ortiz-Gonzalez XR, Reyes M, Lenvik T, Lund T, Blackstad M, Du J, Aldrich S, Lisberg A, Low WC, Largaespada DA, Verfaillie CM. Pluripotency of mesenchymal stem cells derived from adult marrow. Nature. 2002;418(6893):41-9.

3. Domen J, Weissman IL. Self-renewal, differentiation or death: regulation and manipulation of hematopoietic stem cell fate. Mol Med Today. 1999;5(5):201-8.

4. Brazelton TR, Rossi FMVi, Keshet GI, Blau HM. From marrow to brain: expression of neuronal phenotypes in adult mice. Science. 2000;290(5497):1775-9.

5. Anderson DJ, Gage FH, Weissman IL. Can stem cells cross lineage boundaries? Nat Med. 2001;7(4):393-5.
6. Lagasse E, Connors H, Al-Dhalimy M, Reitsma M, Dohse M, Osborne I, Wang X, Finegold M, Weissman IL, Grompe MA. Purifield hematopoietic stem cell can differentiate into hepatocytes in vivo. Nat Med. 2000;6(11):1229-34.

7. Leri A, Ajstura J, Anversa P. Cardiac stem cells and mechanisms of myocardial regeneration. Fisiol Rev. 2005;85(4):1373-416.

8. Barros S, Del Carlo RJ, Vargas M, Galvão SR, Maia-Filho A. Auto-enxerto percutâneo de medula óssea em coelhos. I. Coleta, preparo e aplicação. Ciênc Rural. 2001;31(6):1013-8.

9. Connoly JF. Clinical use of marrow osteoprogenitor cells to stimulate osteogenesis. Clin Orthop. 1998;355:257-66.

10. Beltrami A, Barlucchi I, Torella D, Baker M, Limana F, Chimenti S, Kasahara H, Rota M, Musso E, Urbanek K. Adult cardiac stem cells are multipotent and support myocardial regeneration. Cell. 2003;114(6):763-76. 11. Alison MR, Vig P, Russo F, Bigger BW, Amofah E, Themis M, Forbes S. Hepatic stem cells: from inside and outside the liver? Cell Prolif. 2004;37(1):1-21. 12. Laugwitz K1, Moretti A, Lam J, Gruber P, Chen Y, Woodard S, Lin Lz, Cai Cl, Lu Mm, Reth M, Platoshyn O, Yuan Jx, Evans S, Chien Kr. Postnatal is $11+$ cardioblasts enter fully differentiated cardiomyocite lineages. Nature. 2005;433(7026):647-53.

13. Silva Meirelles L, Chagastelles PC, Nardi NB. Mesenchymal stem cells reside in virtually all post-natal organs and tissues. J Cell Sci. 2006;119(Pt11):2204-13.

14. Qiao C, Xu W, Zhu W, Hu J, Qian H, Yin Q, Jiang R, Yan Y, Mao F, Yang H, Wang X, Chen Y. Human mesenchymal stem cells isolated from the umbilical cord. Cell Biol Int. 2008;32(1):8-15.

15. Bianco P, Riminucci M, Kuznetsov S, Robey PG. Multipotential cells in the bone marrow stroma: regulation in the context of organ physiology. Crit Rev Eukaryotic Gene Expr. 1999;9(2):159-73.

16. Kadiyala S, Young RG, Thiede MA, Bruder SP. Culture expanded canine mesenchymal stem cells possess osteochondrogenic potential in vivo and in vitro. Cell Transplant. 1997; 6(2):125-34.

17. Forriol F, Esparza R. Ingeniería tisular: aplicación de las células troncales pluripotenciales em cirúgia ortopédica y traumatológica. Trauma Fund MAPFRE. 2008;19(2): 88-101.

\section{Correspondence:}

Lilian Piñero Eça

Av. Bem-te-vi, 333/134

04524-030 Sao Paulo - SP Brazil

lilian@ipctron.com.br

Received: March 04, 2009

Review: May 06, 2009

Accepted: June 10, 2009

\section{How to cite this article}

Piñero Eça L, Ramalho RB, Oliveira IS, Gomes PO, Pontes P, Ferreira AT, Mazzetti-Vaccari MP. Comparative study of technique to obtain stem cells from bone marrow collection between the iliac crest and the femoral epiphysis in rabbits. Acta Cir Bras. [serial on the Internet] 2009 Sept-Oct;24(5). Available from URL: http://www.scielo.br/acb

*Color figures available from www.scielo.br/acb 